\title{
Giant buttercup (Ranunculus acris L.) management in dairy pastures - current problems and future solutions
}

\author{
G.W. BOURDÔT and S. LAMOUREAUX \\ AgResearch, PO Box 60, Lincoln 8175, New Zealand \\ graeme.bourdot@agresearch.co.nz
}

\begin{abstract}
Giant buttercup (Ranunculus acris L.) is estimated to cost the New Zealand dairy industry $\$ 118$ million annually in lost milksolid production opportunity through the exclusion of palatable pasture species. Historical reliance by dairy farmers on annual or biennial applications of the 'phenoxy' herbicides MCPA and $\mathrm{MCPB}$, has led to the widespread evolution of phenoxy-herbicide-resistant populations of the weed. The newer herbicides, thifensulfuron methyl and flumetsulam are now being used against giant buttercup, although thifensuluron, like MCPA, can cause clover damage and as a result may promote the growth of giant buttercup populations. In this paper we review the history of giant buttercup management on New Zealand dairy farms and the science that led to the discovery of the herbicide resistance. We also attempt to define a path toward sustainable ecologically-based management of this weed based upon an improved understanding of its population dynamics and the use of a pasture-selective mycoherbicide utilizing the naturally-occurring fungus, Sclerotinia sclerotiorum.
\end{abstract}

Keywords: dairy pasture, economics, giant buttercup, herbicide resistance, mycoherbicide, opportunity cost, population dynamics, Ranunculus acris, weed

\section{Introduction}

Giant buttercup (Ranunculus acris L.) occurs in waste land, roadsides, river flats, swamp margins and pastures in New Zealand (Webb et al. 1988). It is a common weed of dairy pastures in the Tasman district (Bourdôt \& Hurrell 1990), in pastures in the South Auckland, Hawkes Bay and Taranaki regions, and in the districts of South Wairarapa and Horowhenua (Tuckett 1961). While it is absent from most dairy pastures in Canterbury and Southland, localized populations, mainly on nonagricultural land pose a threat to dairy pastures in these regions. Giant buttercup may also occur in pastures grazed by sheep and other livestock, but is not a serious weed in such pastures, usually persisting as stunted plants that fail to reach above the pasture canopy.

Giant buttercup replaces pasture grasses and clovers in dairy pastures through competition and is toxic to dairy cattle when eaten due the production of an acridtasting glycoside, ranunculin (Conner 1977). Both giant buttercup and neighbouring pasture plants are avoided by grazing dairy cattle (Harper \& Sagar 1953).

\section{Economic impact}

Since giant buttercup replaces useful pasture species and is essentially not palatable to dairy cows, the opportunity cost of its presence on a dairy farm can be considered equal to the potential production value of the land area that it covers. A key assumption is that the gain in pasture dry matter made available by removing giant buttercup on infested farms would be translated into a gain in milk solid production by improved per cow performance and/ or increase in herd size. This assumption is reasonable given the concern expressed about the production impacts of giant buttercup particularly in the Taranaki region and the Tasman district where the weed is included in Regional Pest Management Strategies.

In a recent study applying this concept, the seasonal progression of the weed's ground cover in dairy pastures in the Tasman district was measured. This was used in conjunction with monthly pasture dry matter production values (excluding pasture conserved as hay and silage and restricting calculations to the milking season) to estimate the mean annual percentage loss in pasture production due to giant buttercup in a paddock. This estimation assumed that the conversion of pasture dry matter to milk solids is constant throughout the milking season. Calculations using this weighted mean paddock-scale annual loss, $33.2 \%$, an estimate of dairypasture land in the Tasman district infested, 30\% (estimated by local regional council and dairy industry consultants), and the monetary value of milk solid production in the district, NZ\$65 million (calculated from data in "Dairy Statistics 1999-2000" (Anonymous 2000)), revealed an opportunity cost for giant buttercup in the Tasman district of NZ\$7.2 million p.a. at 20002001 prices. The opportunity costs of giant buttercup in the five other regions/districts known to be infested were estimated assuming that the $33.2 \%$ annual loss in pasture dry matter production measured in Tasman applies equally to infested pastures in these other regions; data were not available for these regions. The areas of dairy pasture land infested in these districts were estimated by local regional council and dairy industry consultants to be $5,10,35,10$ and $10 \%$ for South Auckland, Hawkes Bay, Taranaki, South Wairarapa and Horowhenua respectively. The estimated opportunity costs were summed across the six regions/ districts giving a national opportunity cost of $\$ 118$ million p.a. 
This is a conservative estimate of the opportunity cost incurred by the New Zealand dairy industry due to giant buttercup because the method used to calculate it does not account for (1) reduction in the productivity of pasture species in the close vicinity of the buttercup plants through competition, (2) reduction in the utilization of this nearby pasture by grazing animals, (3) losses in dairy cow performance as a consequence of unintentional ingestion of the buttercup, (4) costs of ineffective herbicides and other ineffective control measures or (5) damage to pastures caused by these herbicides.

\section{Herbicides and herbicide resistance}

Historically, the phenoxy herbicides MCPA and MCPB have been relied upon by many NZ dairy farmers for the control of giant buttercup (Bourdôt et al. 1990a; Bourdôt et al. 1990b; Langford 1983). Whilst these herbicides gave adequate control during the 1950s and 1960s following their introduction in the late 1940s and early $1950 \mathrm{~s}$, and at the time represented a major advance in weed control technology, twenty five to thirty years later many farmers where reporting poor control. By 1988 a research programme begun in the early 1980 s by the Agricultural Research Division of the Ministry of Agriculture and Fisheries had shown that the seedling progeny of giant buttercup populations from different dairy farms in Golden Bay, Tasman, varied widely in their tolerance of MCPA (Bourdôt \& Hurrell 1988). Extending this research to dairy farms in Taranaki, Wairarapa and Hawkes Bay, the same degree of betweenfarm variability in MCPA response was discovered (Bourdôt et al. 1990a). This between-population variation in the MCPA-response of North Island seedling progeny paralleled the level of control achieved in the field by the farmers, supporting the hypothesis that poor field control, was due to genetically-based herbicide resistance. The research also showed that the degree of resistance shown by giant buttercup populations was correlated positively with the frequency of historical applications of MCPA and MCPB (Bourdôt et al. 1990a; Bourdôt et al. 1990b). This supported the hypothesis that the resistance had resulted from the selection for a gene or genes conferring herbicide resistance.

Later work confirmed that MCPA resistance is a heritable trait in giant buttercup and thus that giant buttercup populations can evolve MCPA-resistance given sufficiently high selection pressure (Bourdôt \& Hurrell 1991). A computer simulation of the phenology of giant buttercup in New Zealand, with parameter values for seed production taken from a New Zealand study (Popay et al. 1989), and for mortality rates from overseas (Sarukhán 1974; Sarukhán \& Gadgil 1974; Sarukhán \& Harper 1973), confirmed that the winter and spring applications of MCPA made by most farmers result in high selection pressure (Leathwick \& Bourdôt 1991). Further experimental observations indicated that MCPAresistant biotypes of giant buttercup are only slightly less ecologically fit than their susceptible counterparts and that MCPA treatment would need to be withheld from a resistant population for 28 years for it to return to a level of susceptibility enabling MCPA to give effective control (Bourdôt et al. 1996).

Adding to the problem of phenxoy herbicide resistance is the fact that MCPA, the chemical of choice by many dairy farmers because of its low cost, is also very damaging to the clovers in a dairy pasture (Hurrell \& Bourdôt 1993; Popay et al. 1989). Repeated use of this now widely ineffective herbicide, will, by reducing the vigour of the pasture, tend to promote seedling recruitment and population growth in giant buttercup populations. Two recently introduced herbicides (thifensulfuron methyl, "Harmony" and flumetsulam "Preside") are now widely used against giant buttercup in dairy pastures. However, like MCPA, Harmony can result in the loss of clovers (Walton 2001), reducing the pasture's competitive ability and promoting the recruitment of giant buttercup seedlings.

\section{Population dynamics}

The population dynamics of giant buttercup, has not been the subject of scientific enquiry in New Zealand, yet understanding how population size changes over time is crucial to the development of an effective management programme. Such understanding allows scientists to test and explain the outcome of alternative control methods, and enables farmers to make informed choices in developing a management strategy for their farm.

In a landmark weed population study, the contributions that reproduction, recruitment, and survivorship of adult plants and seedlings make to population growth in giant buttercup were measured over three years in coastal grasslands of North Wales (Sarukhán \& Harper 1973) and (Sarukhán 1974). This work showed that giant buttercup reproduces mainly through seed although some vegetative reproduction occurs. Although the seeds have a hook that allows attachment to grazing cows, this does not seem to constitute a well developed dispersal mechanism; clumping of seedlings near parent plants implies most seeds disperse only short distances (Harper 1957). However, cows may ingest considerable numbers of seeds which pass through the digestive system unharmed (Sarukhán 1974). Dore \& Raymond (1942) estimated that one cow could 'disperse' ca. 22000 seeds/ ha in a 165-day grazing season.

There is no evidence of a long lived seed bank in giant buttercup. As a result of high annual losses due to germination (up to $95 \%$ in spring), most seeds of giant buttercup may last no longer than 15 months in the soil 
(Williams 1983). A minority of seeds may survive for 3 years (Roberts \& Boddrell 1985), with most being lost from the seed bank within 12 months of entry (Sarukhán 1974).

While the studies by Sarukhán \& Harper (1973) and Sarukhán (1974) provide a valuable underpinning to the basic ecology of giant buttercup, there exist some major gaps in our ecological understanding of the species. For example, Sarukhán \& Harper (1973) and Sarukhán (1974) were unable to properly assess the density dependent processess regulating the population dynamics of this weed. They did not estimate the parameters of migration to explain local extinctions and recolonisations, nor were they able to estimate the life expectancy of plants older than one year, although they did show that mortality in seedlings is high with less than $20 \%$ surviving their first year (Sarukhán 1974). In addition, many of the population parameters examined by Sarukhán vary between habitats (Hemborg 1998), making it hazardous to extrapolate the Welsh studies to New Zealand dairy pastures.

Models constructed from data on fecundity, recruitment and survival, and the effects of control methods (e.g. herbicides, biological control, grazing management, pasture renovation) on these processes can be used to determine the control method that will cause a giant buttercup population to decline (Cousens \& Mortimer 1995). Such studies have rarely been conducted for any weed but hold promise for using data such as the mortality rate of adult plants following herbicide treatment, to make a prediction of the consequences for population change in the weed (Cousens \& Mortimer 1995).

\section{Potential for biological control}

Several microbial pathogens occur on giant buttercup. One of these, the plant pathogenic fungus Sclerotinia sclerotiorum causes a watery soft-rot disease which results in the death of infected plants. The disease is often seen at the flowering or seeding stage when infected plants are readily uprooted as a result of decay of the rhizome and roots. Recent studies have explored the potential of S. sclerotiorum as a mycoherbicide for giant buttercup management. In a controlled environment study, S. sclerotiorum applied as a mycelium-on-kibbled-wheat preparation to the axils of young rosette leaves of 3month old plants caused $75 \%$ mortality within 21 days (Green et al. 1993). In dairy pastures, 57 and 50\% reduction in the dry weight and ground cover respectively of the weed has been measured following a single application of the fungus (Cornwallis et al. 1999; Harvey \& Bourdôt 2001). These lower levels of control of field populations than expected from the controlled environment study are probably due in part to the older and larger plants in field populations being more resistant and/or more able to re-grow after infection (Green et al. 1994; Green et al. 1993). It has been speculated that higher levels of control in dairy pastures may be achieved by combining $S$. sclerotiorum with some other form of stress that influences regeneration such as defoliation (Green et al. 1996). Research is planned to test this hypothesis and a study of the infection process in $S$. sclerotiorum is underway with a view to enhancing the formulation of this pathogen.

S. sclerotiorum is a wide-host-range pathogen that produces spores that travel in air currents. As a consequence its use as a mycoherbicide in dairy pasture may present a disease risk to neighbouring crops. Recent investigations have shown however that very few of the ascospores released from apothecia formed on overwintered sclerotia in the spring following the control of giant buttercup escape the dense canopy typical of a dairy pasture (de Jong et al. 2002). As a result, susceptible crops could be safely grown immediately beyond a treated dairy pasture; no safety zone is required (Bourdôt et al. 2001).

Not only is $S$. sclerotiorum able to kill giant buttercup plants in dairy pasture with negligible risk to neighbouring crops, it is, also harmless to pasture grasses and clovers (Hurrell \& Bourdôt 1993), unlike many of the chemical herbicides in current use. The fungus is also easy to grow in culture being a facultative parasite. Together these attributes make it an excellent mycoherbicide candidate for giant buttercup management in dairy pasture, and also for other susceptible weeds in pastures, in particular, Californian thistle (Bourdôt et al. 1993; Bourdôt et al. 1995; Hurrell et al. 2001). Despite these benefits, a commercial product is not yet available. Impediments to the commercialization of $S$. sclerotiorum as a myocherbicide for pasture weed control include; (1) current formulations are not always effective in the field (Hurrell et al. 2001), (2) possible high costs of production, (3) a requirement for high field application rates (and hence costs) with current formulations and (4) doubt about the size of the market for such a product. Current research projects are aiming to improve the formulation of $S$. sclerotiorum based on an improved understanding of the infection process.

\section{REFERENCES}

Anonymous 2000. 1999/2000 Dairy Statistics. Livestock Improvement Corporation Limited, Hamilton. 45 pp. Bourdôt, G.W.; Harvey, I.C.; Hurrell, G.A.; Alexander, R.T. 1993. An experimental mycoherbicide utilizing Sclerotinia sclerotiorum controls pasture populations of Cirsium arvense in Canterbury. Proceedings of the New Zealand Plant Protection Conference 46: 251256. 
Bourdôt, G.W.; Harvey, I.C.; Hurrell, G.A.; Saville, D.J. 1995. Demographic and biomass production consequences of inundative treatment of Cirsium arvense with Sclerotinia sclerotiorum. Biocontrol Science and Technology 5: 11-25.

Bourdôt, G.W.; Hurrell, G.A. 1988. Differential tolerance of MCPA among giant buttercup (Ranunculus acris) biotypes in Takaka, Golden Bay. Proceedings of the New Zealand Weed and Pest Control Conference 41: 231-234.

Bourdôt, G.W.; Hurrell, G.A. 1990. Effects of annual treatments of MCPA and MCPB on giant buttercup (Ranunculus acris L.) in dairy pastures. Proceedings of the New Zealand Weed and Pest Control Conference 43: 233-236.

Bourdôt, G.W.; Hurrell, G.A. 1991. Evidence for the heritability of MCPA-resistance in giant buttercup (Ranunculus acris). Proceedings of the New Zealand Weed and Pest Control Conference 44: 270-274.

Bourdôt, G.W.; Hurrell, G.A.; de Jong, M.D. 2001. Risk analysis of Sclerotinia sclerotiorum as a mycoherbicide for pasture weed control in New Zealand. In: Proceedings of the XIth International Sclerotinia Workshop" pp. 85-86 Eds. Young, C.; Hughes, K., British Society for Plant Pathology \& International Society for Plant Pathology.

Bourdôt, G.W.; Hurrell, G.A.; Saville, D.J. 1990a. MCPA-resistance in giant buttercup (Ranunculus acris L.) in North Island dairy pastures. Proceedings of the New Zealand Weed and Pest Control Conference 43: 229-232.

Bourdôt, G.W.; Hurrell, G.A.; Saville, D.J. 1990 b. Variation in MCPA-resistance in Ranunculus acris L. subsp. acris and its correlation with historical exposure to MCPA. Weed Research 30: 449-457.

Bourdôt, G.W.; Saville, D.J.; Hurrell, G.A. 1996. Ecological fitness and the decline of resistance to the herbicide MCPA in a population of Ranunculus acris. Journal of Applied Ecology 33: 151-160.

Conner, H.E. 1977. The poisonous plants in New Zealand. NZ DSIR, E.C. Keating - Government Printer, Wellington. $247 \mathrm{pp}$.

Cornwallis, L.J.; Stewart, A.; Bourdôt, G.W.; Gaunt, R.E.; Harvey, I.C.; Saville, D.J. 1999. Pathogenicity of Sclerotinia sclerotiorum on Ranunculus acris in dairy pasture. Biocontrol Science and Technology 9: 365-377.

Cousens, R.D.; Mortimer, M. 1995. Dynamics of Weed Populations. Cambridge University Press, Cambridge. $332 \mathrm{pp}$.

de Jong, M.D.; Bourdôt, G.W.; Powell, J.; Goudriaan, J. 2002. A model of the escape of Sclerotinia sclerotiorum ascospores from pasture. Ecological Modelling 150: 83-150.
Dore, W.G.; Raymond, L.C. 1942. Viable seeds in pasture soil and manure. Scientific Agriculture 23: 69-79.

Green, S.; Bourdôt, G.W.; Field, R.J.; Harvey, I.C. 1994. Resistance of Ranunculus acris crown tissue enables survival after infection by Sclerotinia sclerotiorum. Proceedings of the New Zealand Plant Protection Conference 47:58-61.

Green, S.; Gaunt, R.E.; Bourdôt, G.W.; Harvey, I.C. 1996. The potential of Sclerotinia sclerotiorum as a mycoherbicide for Ranunculus acris, a perennial pasture weed in New Zealand. In: Proceedings of the 2nd International Weed Control Congress" pp. 13171321 Eds. Brown, H., Flakkebjerg, Denmark, Dept. of Weed Control \& Pesticide Ecology, IV.

Green, S.; Saville, D.J.; Bourdôt, G.W.; Harvey, I.C.; Field, R.J.; Close, R.C. 1993. Regeneration sites of Ranunculus acris are the target for Sclerotinia sclerotiorum, a potential mycoherbicide. Proceedings of the New Zealand Plant Protection Conference 46: 274-277.

Harper, J.L. 1957. Biological flora of the British Isles Ranunculus acris L. (R. acer auct. plur). Journal of Ecology 45: 289-342.

Harper, J.L.; Sagar, G.R. 1953. Buttercups, Some aspects of the ecology of buttercups in permanent grassland. In: British weed control conference" pp. 256-263 Eds. Woodford, E. K., British Crop Protection Council, 1. Harvey, I.C.; Bourdôt, G.W. 2001. Giant buttercup (Ranunculus acris L.) control in dairy pasture using a mycoherbicide based on Sclerotinia sclerotiorum. New Zealand Plant Protection 54: 120-124.

Hemborg, Å.M. 1998. Costs of reproduction in subarctic Ranunculus acris: a five-year field experiment. Oikos 83: 273-282.

Hurrell, G.A.; Bourdôt, G.W. 1993. Pasture grasses and white clover unaffected by an inundative application of Sclerotinia sclerotiorum. Proceedings of the New Zealand Plant Protection Conference 46: 257-260.

Hurrell, G.A.; Bourdôt, G.W.; Saville, D. 2001. Effect of application time on the efficacy of Sclerotinia sclerotiorum as a mycoherbicide for Cirsium arvense control in pasture. Biocontrol Science and Technology 11: 317-330.

Langford, P. 1983. Giant buttercup control in Golden Bay. In: Golden Bay Dairy Farmers' Conference pp. 46-49 Eds. MAF, Ministry of Agriculture and Fisheries.

Leathwick, D.M.; Bourdôt, G.W. 1991. Application time influences the development of herbicide resistance in giant buttercup (Ranunculus acris). Proceedings of the New Zealand Weed and Pest Control Conference 44: 275-279.

Popay, A.I.; Edmonds, D.K.; Lyttle, L.A.; Phung, H.T. 1989. Chemical control of giant buttercup (Ranunculus 
acris L.). New Zealand Journal of Agricultural Research 32: 299-303.

Roberts, H.A.; Boddrell, J.E. 1985. Seed survival and seasonal emergence in some species of Geranium, Ranunculus and Rumex. Annals of Applied Biology 107: 231-238.

Sarukhán, J. 1974. Studies on plant demography: Ranunculus repens L., R. bulbosus L. and $R$. acris L. II. Reproductive strategies and seed population dynamics. Journal of Ecology 62: 151-177.

Sarukhán, J.; Gadgil, M. 1974. Studies on plant demography: Ranunculus repens $\mathrm{L}$., $R$. bulbosus $\mathrm{L}$. and $R$. acris L. III. A mathematical model incorporating multiple modes of reproduction. Journal of Ecology 62: 921-936.

Sarukhán, J.; Harper, J.L. 1973. Studies on plant demography: Ranunculus repens, L., R. bulbosus L. and $R$. acris L. I. Population flux and survivorship. Journal of Ecology 61: 675-716.

Tuckett, A.J. 1961. Giant buttercup. Proceedings of the New Zealand Weed and Pest Control Conference14: 124-126.

Walton, T. 2001. Weeds. pp. 1-123. In: New Zealand Agrichemical Manual. Eds. Walton, T.; Fletcher, L.; Fouhy, E.; Hutching, B. Fusell \& Walton, Wellington. Webb, C.J.; Sykes, W.R.; Garnock-Jones, P.J. 1988. Flora of New Zealand. Volume IV. Naturalised Pteridophytes, Gymnosperms, Dicotyledons. Botany Division, DSIR, New Zealand, Christchurch. 1365 pp.

Williams, E.D. 1983. Germinability and enforced dormancy in seeds of species of indigenous grasslands. Annals of Applied Biology 102: 557-566. 